\title{
kazuistụczne
}

Kacper Nijakowski', Aleksandra Klimek², Kinga Andrysiak², Zuzanna Dorawa²,

Filip Fagiewicz², Karolina Soboczyńska', Anna Surdacka'

\section{Wielokanałowe drugie zęby przedtrzonowe szczęki — opis przypadków}

\author{
Multicanal maxillary second premolars — case reports
}

\begin{abstract}
${ }^{1}$ Klinika Stomatologii Zachowawczej i Endodoncji, Uniwersytet Medyczny im. Karola Marcinkowskiego w Poznaniu
2 Studenckie Koło Naukowe przy Klinice Stomatologii Zachowawczej i Endodoncji, Uniwersytet Medyczny im. Karola Marcinkowskiego w Poznaniu
\end{abstract}

DOI: http://dx.doi.org/10.20883/df.2018.34

\begin{abstract}
STRESZCZENIE
Statystycznie w drugich zębach przedtrzonowych szczęki w ok. 90\% przypadków obserwuje się jeden korzeń, a w blisko 80\% jeden kanał korzeniowy. Jednakże można spotkać dwa kanały czy korzenie, jak również niewielki odsetek z trzema korzeniami. Celem pracy jest przedstawienie, zebranych przez studentów, przypadków klinicznych leczenia endodontycznego drugich zębów przedtrzonowych szczęki z więcej niż jednym kanałem korzeniowym.
\end{abstract}

Słowa kluczowe: drugie zęby przedtrzonowe szczęki, kanał korzeniowy, anatomia.

\section{ABSTRACT}

Statistically, in about $90 \%$ cases one root and in nearly $80 \%$ one canal is observed in maxillary second premolars. However, there are also two canals or roots and even a small percentage with three roots. The aim of the study is to present student case reports of the endodontic treatment of the maxillary second premolars with more than one root canal.

Keywords: maxillary second premolars, root canal, anatomy.

\section{Wstęp}

Sukces leczenia endodontycznego zależy od wielu czynników. Należą do nich m.in. wykonanie diagnostycznego zdjęcia rentgenowskiego leczonego zęba, jak również prawidłowe przygotowanie dostępu celem odnalezienia ujść wszystkich kanałów. Powodzenie leczenia endodontycznego będzie zależne także od chemomechanicznego opracowania wszystkich kanałów, ich poprawnej obturacji oraz szczelnej odbudowy korony zęba. Anatomia kompleksu kanałowego zębów potrafi zaskoczyć nawet endodontów. Statystycznie w drugich zębach przedtrzonowych szczęki w ok. $90 \%$ przypadków obserwuje się jeden korzeń, a w blisko 80\% jeden kanał korzeniowy. Jednakże spotyka się dwa kanały czy korzenie, jak i nawet niewielki odsetek (ok. 1\% pacjentów) z trzema korzeniami [1]. Występujący wówczas układ korzeni jest podobny do "Wyszczuplonego" zęba trzonowego z dość wąskimi kanałami. W pracy zostaną przedstawione studenckie przypadki kliniczne obrazujące leczenie endodontyczne drugich zębów przedtrzonowych szczęki z więcej niż jednym kanałem korzeniowym w Klinice Stomatologii Zachowawczej i Endodoncji Uniwersytetu Medycznego w Poznaniu. Wszystkie prezentowane zdjęcia radiowizjograficzne zostały wykonane w Pracowni Radiologii Stomatologicznej Uniwersytetu Medycznego w Poznaniu w projekcjach zaznaczonych na skierowaniu.

\section{Przypadek 1}

Pacjent Ł.G., lat 21, zgłosił się do Kliniki Stomatologii Zachowawczej i Endodoncji w celu przeglądu stomatologicznego. W badaniu podmiotowym pacjent szczególnie uskarżał się na dolegliwości bólowe, także nocne, zęba 15. Natomiast $w$ badaniu klinicznym stwierdzono potrzebę leczenia zachowawczego kilku zębów, a w zębie 15 rozległy ubytek próchnicowy na powierzchni mezjalnej z dodatnim wynikiem testu żywotności miazgi. W oparciu o badanie podmiotowe i przedmiotowe postawiono rozpoznanie nieodwracalnego zapalenia miazgi z żywą miazgą. Otrzymano zgodę pacjenta na proponowane leczenie endodontyczne. 
W znieczuleniu nasiękowym Citocartin 200 opracowano ubytek, dokonano trepanacji i opracowania komory zęba oraz odszukano ujścia dwóch kanałów. Wstępnie udrożniono kanał podniebienny pilnikiem $C$ o rozmiarze 10 i policzkowy o rozmiarze $6 \mathrm{wg}$ ISO. Dodatkowo wąski kanał policzkowy dość wyraźnie skierowany był dystalnie. W celu dokładniejszej analizy przebiegu systemu kanałowego wykonano zdjęcie radiowizjograficzne z pilnikami w projekcji skośnej przednio-tylnej (Rycina 1). Na podstawie zdjęcia stwierdzono trzykorzeniową budowę zęba 15, co jest bardzo rzadko spotykanym typem systemu korzeniowego w zębach przedtrzonowych. Kanały policzkowe posiadały wspólne ujście i rozchodziły się ok. 2-3 mm poniżej dna komory. W związku z ograniczeniem czasowym zajęć studenckich jeszcze na tej wizycie odbudowano ścianę mezjalną materiałem kompozytowym, wyekstyrpowano miazgę z odnalezionego kanału policzkowego bliższego, do komory założono sterylną watkę z preparatem Dexadent oraz opatrunek tymczasowy.

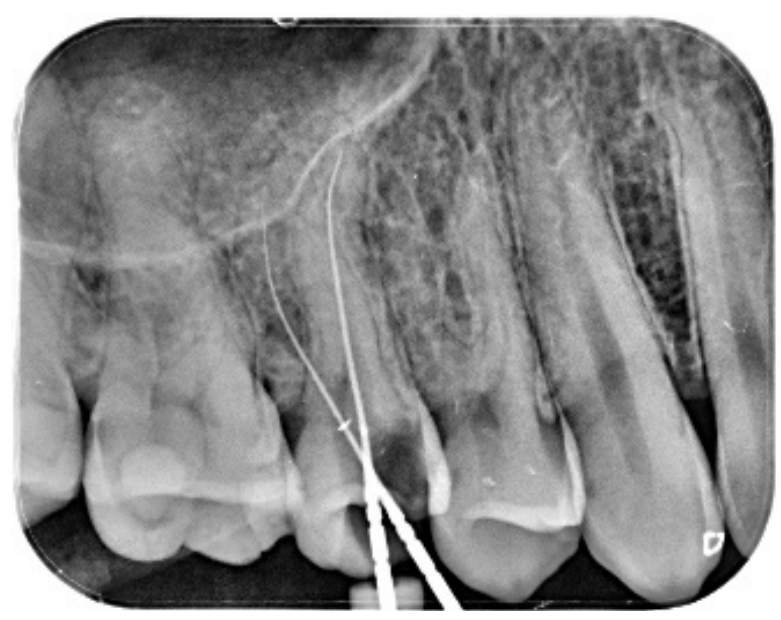

Rycina 1. Zdjęcie rentgenowskie z pilnikami (projekcja skośna przednio-tylna) — przypadek 1

Figure 1. Radiograph with files (mesial projection) - case 1

Na następnej wizycie pacjent nie zgłaszał dolegliwości bólowych. Po założeniu koferdamu kontynuowano leczenie endodontyczne. Ujścia kanałów policzkowych opracowano za pomocą wierteł Gates-Glidden przeprowadzono chemomechaniczne opracowanie systemu korzeniowego narzędziami ręcznymi typu $\mathrm{K} \mathrm{z}$ wykorzystaniem lubrykantu EndoPrepCream. Do wyznaczenia długości roboczych skorzystano $z$ dostępnego w Klinice endometru C-Root Vl. Kanały policzkowe mezjal- ny i dystalny opracowano do MAF 30 na długości $19,5 \mathrm{~mm}$, a podniebienny do MAF 35 na $21,5 \mathrm{~mm}$. Za punkty referencyjne określono odpowiadające kanałom ściany policzkową i podniebienną. Płukano $2 \%$ podchlorynem sodu. Po osuszeniu kanałów wykonano zdjęcie kontrolne z wcześniej przymierzonymi ćwiekami głównymi (Rycina 2). W ocenie radiologicznej kanały zostały opracowane na prawidłowo oznaczoną długość roboczą - brak widocznego światła kanałów w kierunku wierzchołków radiologicznych. Dodatkowo zaobserwowano, iż ząb 14 posiada analogiczną budowę systemu kanałowego. Ząb został zaopatrzony suchą sterylną watką i materiałem tymczasowym do czasu właściwej obturacji kanałów.

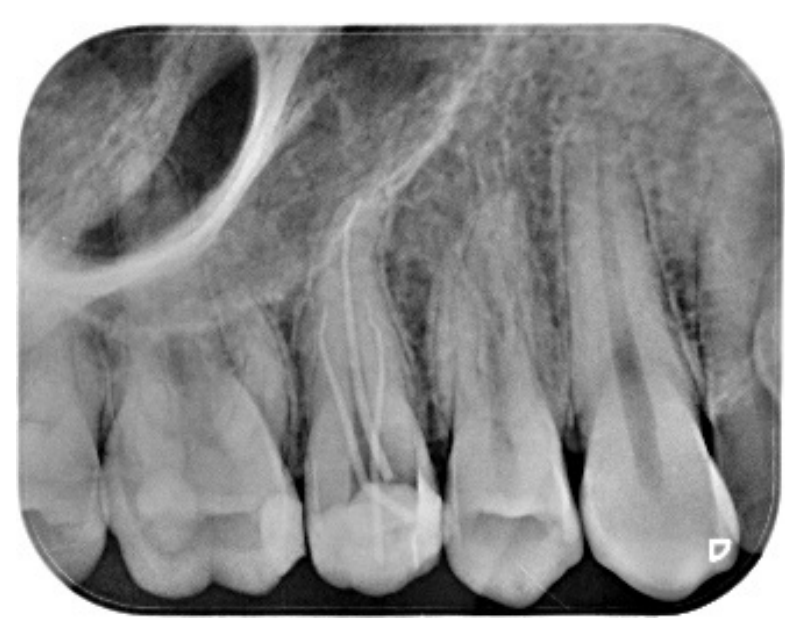

Rycina 2. Zdjęcie rentgenowskie z ćwiekami głównymi (projekcja kąta prostego) - przypadek 1

Figure 2. Radiograph with master apical points (orthoradial projection) - case 1

Kolejną wizytę rozpoczęto od założenia koferdamu i usunięcia opatrunku. Brak dolegliwości bólowych oraz stwierdzony brak wysięku w kanałach pozwalał na wypełnienie wszystkich trzech kanałów metodą kondensacji bocznej gutaperki na zimno $z$ uszczelniaczem (Endomethasone N). Wykonano zdjęcie kontrolne w projekcji kąta prostego, na którym stwierdzono prawidłowo wypełnione kanały korzeniowe - analogicznie do zdjęcia z ćwiekami głównymi (Rycina 3). Dno komory przemyto alkoholem izopropylowym, ujścia kanałów pokryto materiałem typu flow, a ząb zaopatrzono tymczasowo materiałem szkłojonomerowym. Pacjenta poinformowano o konieczności wykonania docelowej odbudowy zęba po zakończonym leczeniu endodontycznym, kontroli radiologicznej za pół roku i kontynuacji leczenia zachowawczego pozostałych zębów. 


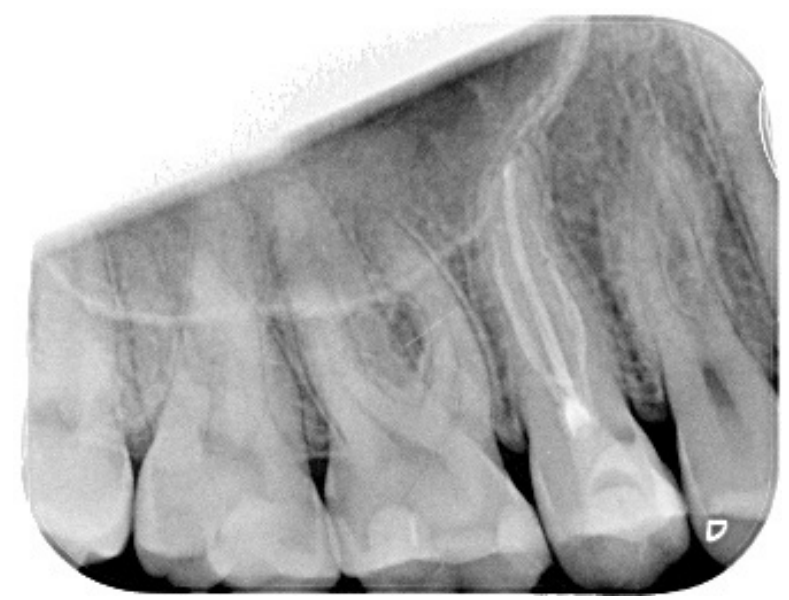

Rycina 3. Zdjęcie rentgenowskie po wypełnieniu kanałów (projekcja kąta prostego) - przypadek 1

Figure 3. Postoperative radiograph (orthoradial projection) - case 1

\section{Przypadek 2}

Pacjentkę K.M., lat 31, skierowano do Kliniki Stomatologii Zachowawczej i Endodoncji w celu kontynuacji leczenia zęba 15. Z wywiadu wiadomo było, że pacjentka wcześniej zgłosiła się do lekarza stomatologa pomocy doraźnej z pulsującym trwającym 2 dni bólem okolicy zęba 15. Dokumentacja medyczna wskazała, że w pierwszym etapie wykonano i oceniono zdjęcie radiologiczne zęba 15 (Rycina 4), na którym widoczne było rozległe nieszczelne wypełnienie, a w zębie 16 niedopełnione kanały i nieszczelna odbudowa twardych tkanek zęba, jak również zatrzymany poziomo ząb 18. Lekarz stomatolog pomocy doraźnej w oparciu o badanie radiologiczne, a przede wszystkim badanie kliniczne zdiagnozował nieodwracalne zapalenie

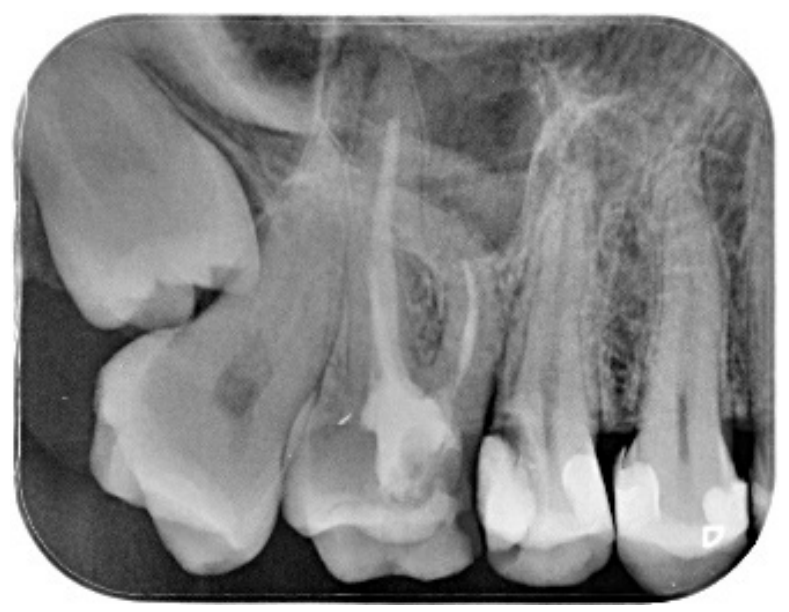

Rycina 4. Zdjęcie rentgenowskie diagnostyczne (projekcja kąta prostego) - przypadek 2

Figure 4. Diagnostic radiograph (orthoradial projection) - case 2 miazgi zęba 15. W znieczuleniu nasiękowym wykonał ekstyrpację zapalnie zmienionej miazgi i ze względu na obfite krwawienie z kanału korzeniowego zaopatrzył ząb opatrunkiem (Dexadent i Coltosol). Następnie skierował pacjentkę do Kliniki Stomatologii Zachowawczej i Endodoncji w celu dalszego leczenia endodontycznego zęba.

Na umówioną wizytę w naszej Klinice pacjentka zgłosiła się już po utracie opatrunku, jednak bez dolegliwości bólowych. Po uzyskaniu zgody pacjentki na proponowane leczenie obniżono guzki korony i odbudowano materiałem kompozytowym brakującą ścianę zęba. Następnie przystąpiono do leczenia kanału zęba 15. System kanałowy okazał się bardziej skomplikowany niż wstępnie zakładał lekarz kierujący. W połowie długości kanału z ujściem w kształcie biszkoptu stwierdzono rozwidlenie na dwa kanały z odrębnymi otworami wierzchołkowymi (typ V systemu kanałowego wg Vertucciego). Długości robocze wyznaczono za pomocą endometru C-Root VI - kanał policzkowy $21 \mathrm{~mm}$, kanał podniebienny $21 \mathrm{~mm}$ (punktami referencyjnymi były odpowiadające im guzki zęba). Przeprowadzono chemomechaniczne opracowanie kanałów policzkowego i podniebiennego stalowymi narzędziami ręcznymi z użyciem lubrykantu EndoPrepCream. Kanał policzkowy poszerzono techniką step-back do rozmiaru MAF 30 wg ISO, a podniebienny do MAF 35. W czasie zabiegu płukano kanały $2 \%$ podchlorynem sodu. Ze względu na ograniczenie czasowe, po osuszeniu kanałów wykonano zdjęcie kontrolne radiowizjograficzne w projekcji przednio-tylnej z uprzednio przymierzonymi ćwiekami głównymi (Rycina 5). Ząb zaopatrzono watką i materiałem tymczaso-

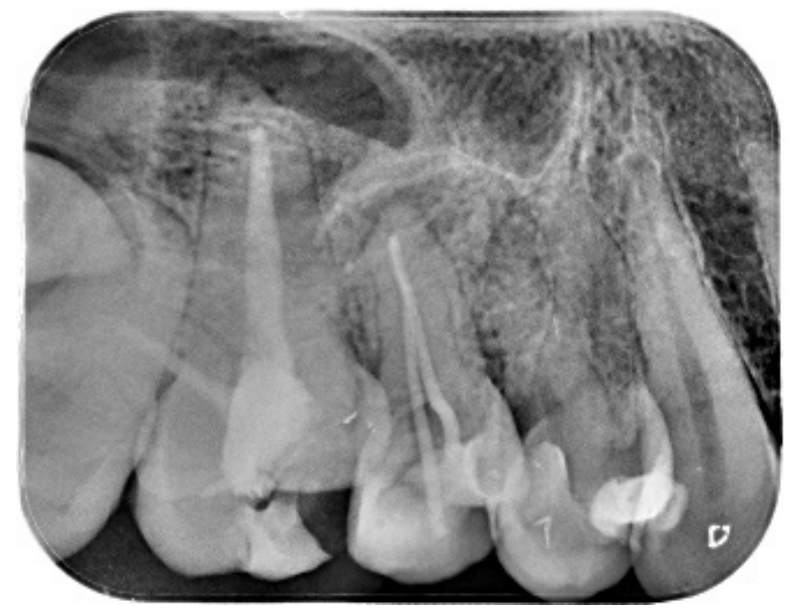

Rycina 5. Zdjęcie rentgenowskie z ćwiekami głównymi (projekcja skośna przednio-tylna) — przypadek 2

Figure 5. Radiograph with master apical points (mesial projection) - case 2 
wym. Na następnej wizycie dopracowano kanał policzkowy na długość o $1 \mathrm{~mm}$ większą, zgodnie ze zdjęciem kontrolnym i wypełniono oba kanały metodą kondensacji bocznej gutaperki na zimno z uszczelniaczem (Endomethasone N). Wykonano zdjęcia kontrolne w projekcji kąta prostego i skośnej przednio-tylnej (Ryciny 6 i 7), na których zaobserwowano prawidłowo wypełnione kanały korzeniowe. Po oczyszczeniu dna komory alkoholem izopropylowym wspólne ujście kanałów pokryto materiałem typu flow, a ubytek w zębie zaopatrzono tymczasowo materiałem szkłojonomerowym. Pacjentkę pouczono o konieczności wykonania ostatecznej odbudowy zęba po leczeniu endodontycznym i kontroli radiologicznej za 6 miesięcy oraz dalszego leczenia stomatologicznego.

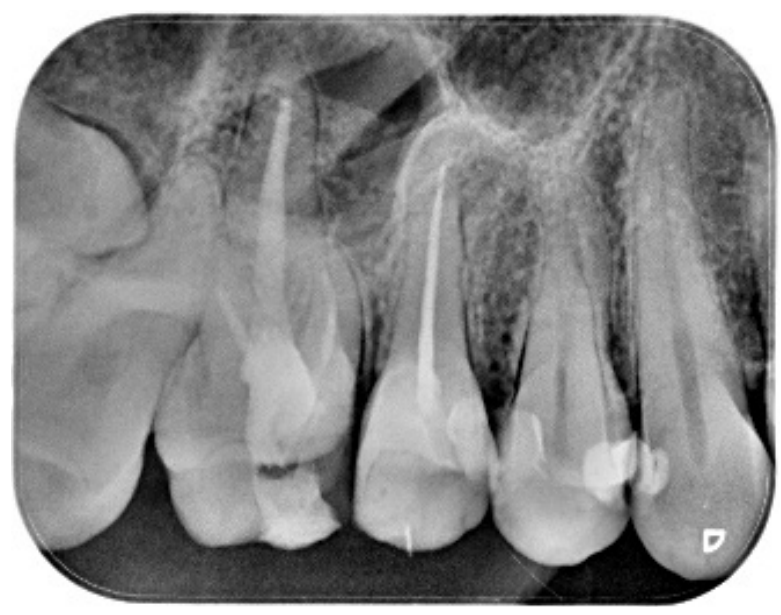

Rycina 6. Zdjęcie rentgenowskie po wypełnieniu kanałów (projekcja kąta prostego) — przypadek 2

Figure 6. Postoperative radiograph (orthoradial projection) - case 2

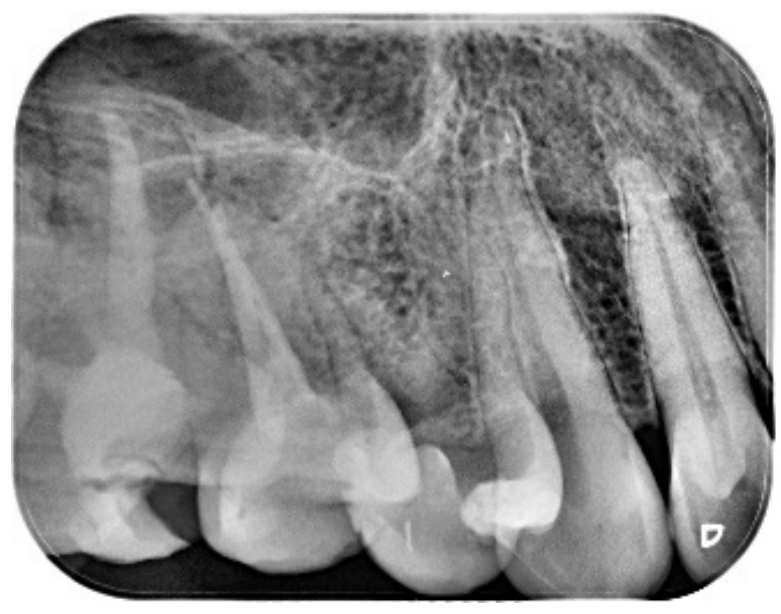

Rycina 7. Zdjęcie rentgenowskie po wypełnieniu kanałów (projekcja skośna przednio-tylna) — przypadek 2

Figure 7. Postoperative radiograph (mesial projection) case 2

\section{Przypadek 3}

Pacjent P.J., lat 43, zgłosił się do Kliniki Stomatologii Zachowawczej i Endodoncji w celu kontrolnego badania uzębienia. W wywiadzie podawał dolegliwości bólowe o różnym nasileniu trwające około 3 dni w okolicy zęba 15 . W badaniu klinicznym stwierdzono kilka zębów, których korony były mocno zniszczone procesem próchnicowym. Wykonano zdjęcie pantomograficzne, na podstawie którego zakwalifikowano zęby 47, 46 i 37, 38 do ekstrakcji. W zębie 15 (Rycina 9 - wycinek panoramy) widoczne obszerne wypełnienie z próchnicą wtórną. Po usunięciu nieszczelnego wypełnienia podjęto próbę usunięcia próchnicowo zmienionych tkanek. Na podstawie wywiadu, badania klinicznego i radiologicznego postawiono ostateczną diagnozę: nieodwracalne zapalenie miazgi. Przystąpiono, po uzyskaniu zgody pacjenta, do dalszych etapów leczenia endodontycznego. Po wykonaniu znieczulenia nasiękowego Citocartin 200 założono koferdam, odbudowano brakującą ścianę materiałem kompozytowym i opracowano komorę zęba. Po oczyszczeniu komory ujawniły się ujścia dwóch kanałów korzeniowych ułożonych policzkowo i podniebiennie. Wyekstyrpowano miazgę i ustalono za pomocą endometru C-Root VI wstępną długość roboczą kanałów na $19 \mathrm{~mm}$ (z punktami referencyjnymi na jednoimiennych guzkach). $Z$ powodu braku czasu pacjenta zaopatrzono ubytek suchą watką i materiałem tymczasowym.

Na następnej wizycie pacjent nie zgłaszał dolegliwości bólowych. Wykonano zdjęcie diagnostyczne w projekcji skośnej przednio-tylnej z pilnikami (Rycina 10) wprowadzonymi na długość $18 \mathrm{~mm}$ do kanału policzkowego (powyżej tej długości pacjent odczuwał dość znaczne dolegliwości bólowe) i na długość $19 \mathrm{~mm}$ do podniebiennego. Zdjęcie radiowizjograficzne potwierdziło obecność dwóch korzeni - typ IV systemu kanałowego wg klasyfikacji Vertucciego. Po analizie zdjęcia i ponownej weryfikacji endometrem, pracując w koferdamie, ustalono ostateczną długość roboczą obu kanałów na $19 \mathrm{~mm}$. Następnie przeprowadzono chemomechaniczne opracowanie kanałów - początkowo narzędziami ręcznymi (pilnikami C rozmiaru $10 \mathrm{wg}$ ISO), a następnie narzędziem maszynowym ProGlider. Do opracowania wykorzystano system maszynowy ProTaper Next (do narzędzia X3) z zastosowaniem mikrosilnika endodontycznego Maillefer X-Smart Plus (prędkość 300 obrotów/minutę, moment obrotowy $2 \mathrm{Ncm}$ ). Płukano $2 \%$ podchlorynem sodu i $40 \%$ kwasem cytrynowym. Wypełniono oba kanały metodą jednego ćwieka o dobranym odpowiednio rozmiarze i stoż- 


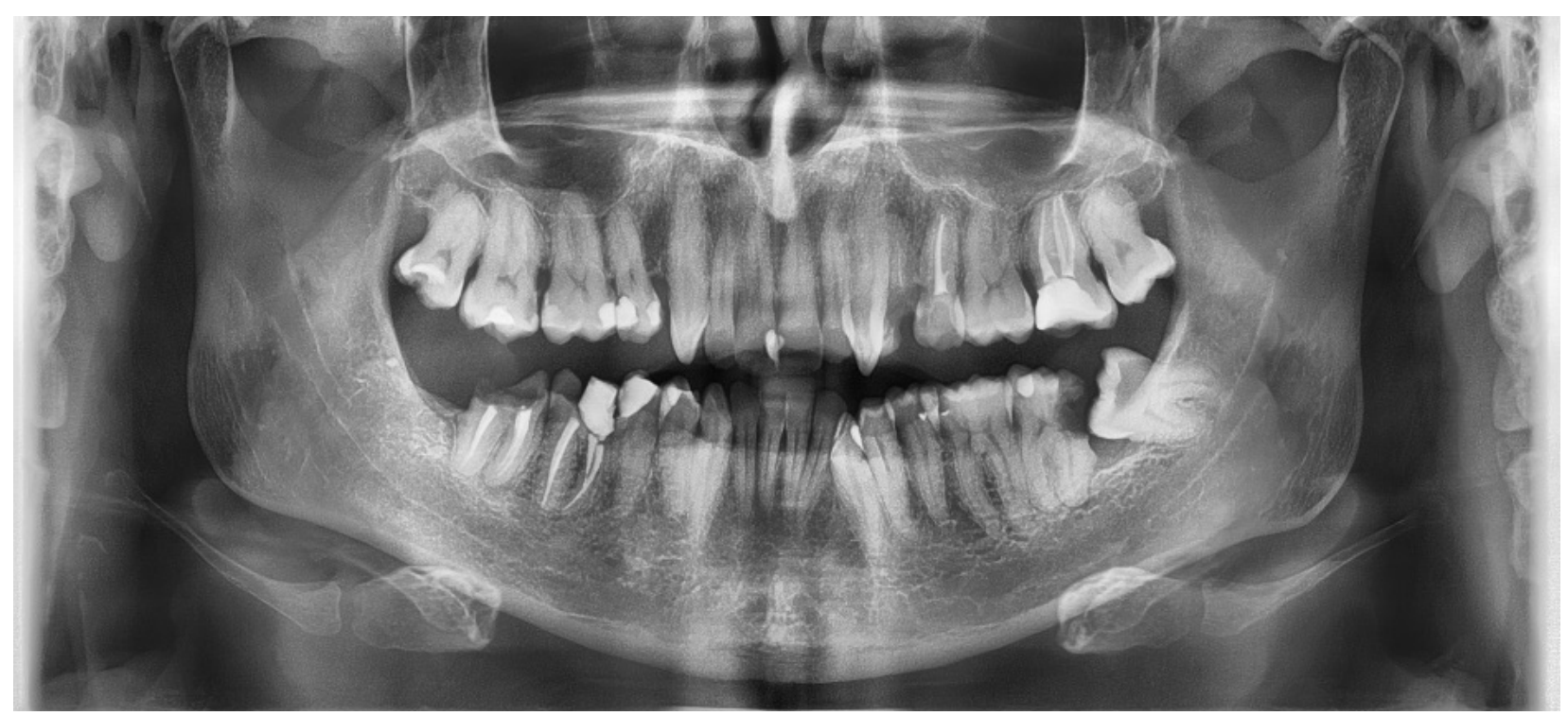

Rycina 8. Zdjęcie pantomograficzne - przypadek 3

Figure 8. Pantomograph - case 3

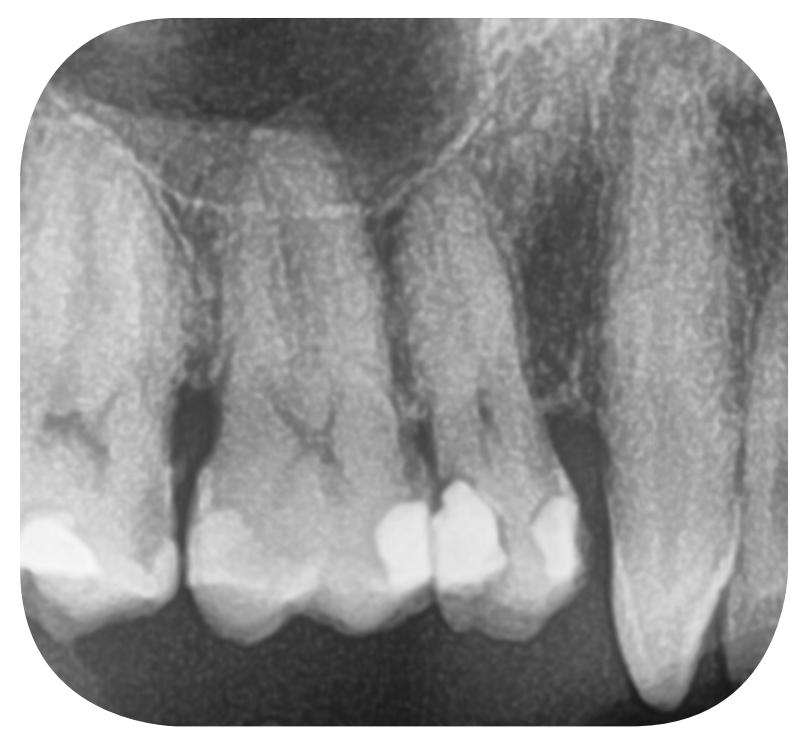

Rycina 9. Wycinek ze zdjęcia pantomograficznego przypadek 3

Figure 9. Fragment of pantomograph - case 3

kowatości wraz z uszczelniaczem (AdSeal). Skierowano pacjenta na zdjęcie kontrolne w projekcji skośnej przednio-tylnej (Rycina 11 - wykonane przez radiologa w projekcji skośnej tylno-przedniej) i stwierdzono prawidłowo wypełniony system kanałowy (bez widocznego dalszego światła kanałów). Oczyszczono dno komory, ujście kanałów pokryto materiałem typu flow, a ząb zaopatrzono tymczasowo materiałem szkłojonomerowym. Po zakończonym leczeniu endodontycznym poinformowano pacjenta o konieczności wykonania ostatecznej odbudowy zęba i kontroli radiologicznej po ok. 6 miesiącach.

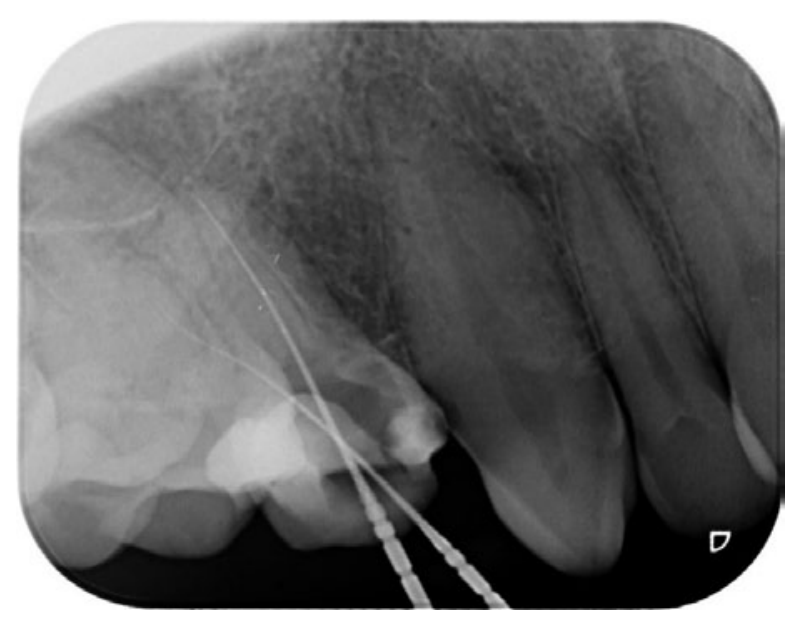

Rycina 10. Zdjęcie rentgenowskie z pilnikami (projekcja skośna przednio-tylna) - przypadek 3

Figure 10. Radiograph with files (mesial projection) — case 3

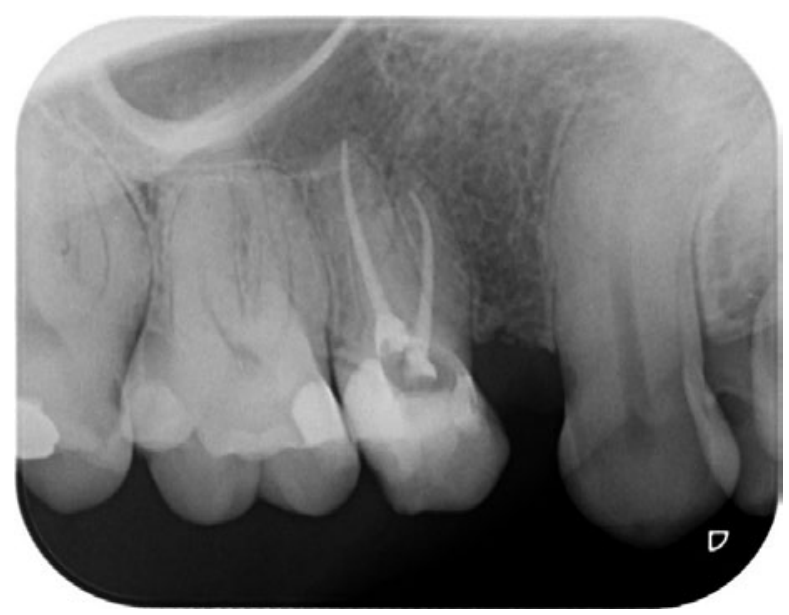

Rycina 11. Zdjęcie rentgenowskie po wypełnieniu kanałów (projekcja skośna tylno-przednia) - przypadek 3

Figure 11. Postoperative radiograph (distal projection) case 3 


\section{Przypadek 4}

Pacjenta A.K., lat 23, skierowano na zajęcia studenckie celem kontynuacji leczenia endodontycznego zęba 15. Wcześniej pacjent zgłosił się do lekarza w innym gabinecie z tętniącym, ostrym bólem zęba 15 . Występujący wówczas silny samoistny ból o charakterze promieniującym sugerował ostre nieodwracalne zapalenie miazgi. Lekarz w znieczuleniu strepanował komorę zęba i wyekstyrpował miazgę z kanału korzeniowego. Dolegliwości ustąpiły.

Podczas wizyty po wykonaniu diagnostycznego zdjęcia radiowizjograficznego (Rycina 12) usunięto rozszczelniony opatrunek, a kanał przepłukano $2 \%$ chlorheksydyną. W trakcie wprowadzania narzędzi zauważono obecność dwóch kanałów: policzkowego i podniebiennego. Długości robocze obu kanałów określono na 23 mm (z punktami

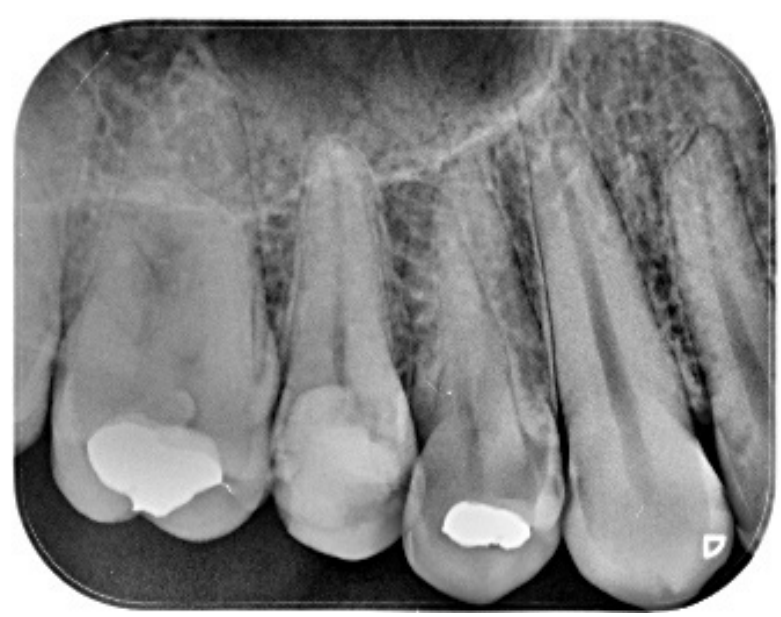

Rycina 12. Zdjęcie rentgenowskie diagnostyczne (projekcja kąta prostego) - przypadek 4

Figure 12. Diagnostic radiograph (orthoradial projection) - case 4

referencyjnymi na odpowiednich guzkach) za pomocą endometru C-Root VI. Przeprowadzono chemomechaniczne opracowanie kanałów do MAF $35 \mathrm{wg}$ ISO stalowymi narzędziami ręcznymi z zastosowaniem lubrykantu EndoPrepCream. Podczas przymiarki ćwieków głównych stwierdzono, iż oba kanały mają wspólne ujście w komorze, jak również wspólny otwór anatomiczny, łącząc się ok. $2 \mathrm{~mm}$ od wierzchołka (typ III systemu kanałowego wg Vertucciego). Wypełniono kanały metodą kondensacji bocznej gutaperki na zimno z uszczelniaczem (Endomethasone $\mathrm{N}$ ) i wykonano zdjęcie kontrolne w projekcji skośnej przednio-tylnej (Rycina 13). Stwierdzono prawidłowo wypełniony system kanałowy, przemyto dno komory al-

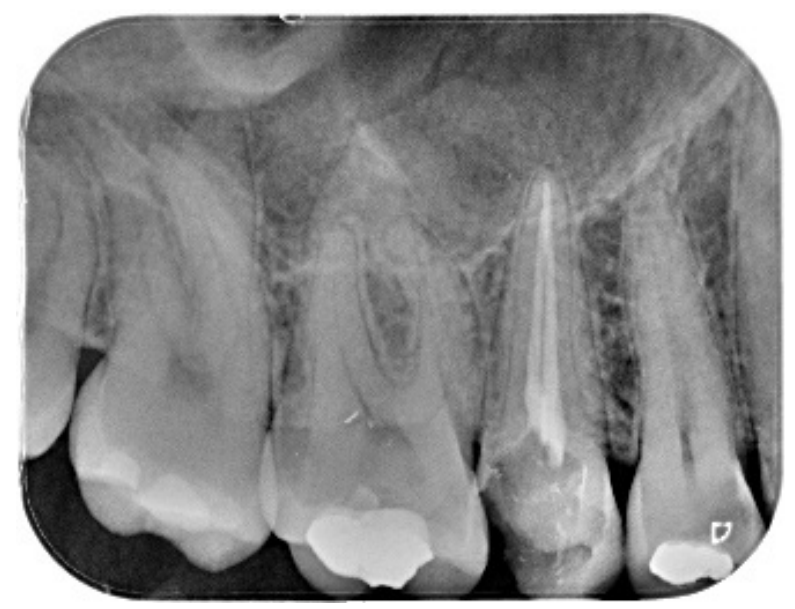

Rycina 13. Zdjęcie rentgenowskie po wypełnieniu kanałów (projekcja skośna przednio-tylna) — przypadek 4

Figure 13. Postoperative radiograph (mesial projection) case 4

koholem izopropylowym, ujście kanałów pokryto materiałem typu flow, a ząb zaopatrzono tymczasowo materiałem szkłojonomerowym. Pacjenta poinformowano o konieczności wykonania ostatecznej odbudowy zęba po zakończonym leczeniu kanałowym i kontroli radiologicznej za 6 miesięcy.

\section{Podsumowanie}

W piśmiennictwie coraz częściej opisywane są przypadki rzadkich postaci morfologicznych systemów kanałowych. Współczesne opisy przypadków klinicznych wskazujące na trzykorzeniowe drugie przedtrzonowce szczęki można spotkać w fachowych czasopismach, w pracach klinicystów z różnych kontynentów [2-9]. Jeszcze ćwierć wieku temu Pecora i wsp. [10], prowadząc badania w warunkach in vitro na 435 usuniętych drugich zębach przedtrzonowych pochodzących z populacji brazylijskiej, nie stwierdzili obecności zębów $z$ trzema korzeniami, a jedynie w $0,3 \%$ zaobserwowali trzy kanały korzeniowe. $Z$ kolei Abella i wsp. [11] $w$ badaniu in vivo za pomocą tomografii stożkowej opisali morfologię systemów kanałowych zębów przedtrzonowych $\mathrm{w}$ populacji hiszpańskiej, uwzględniając 430 pierwszych i 374 drugie zęby przedtrzonowe. Niezależnie od płci, przeważały zęby jednokorzeniowe, jednak pierwsze przedtrzonowce posiadały w $51,4 \%$ dwa korzenie i w 2,6\% trzy, a drugie odpowiednio w 15,5\% dwa i w 1,6\% trzy. Najczęstszymi konfiguracjami systemów korzeniowych były typy I, IV i VIII wg Vertucciego charakteryzujące się oddzielnymi niepołączonymi kanałami.

Mimo pozornie oczywistej budowy drugich zębów przedtrzonowych z przeważającym jednym 
kanałem korzeniowym należy pamiętać o możliwej złożonej morfologii systemów korzeniowych z dwoma bądź nawet trzema kanałami. Niezwykle istotne jest przeprowadzenie diagnostyki radiologicznej w postaci wewnątrzustnego zdjęcia zębowego, a w przypadku wątpliwości badania tomografii komputerowej o wiązce stożkowej (CBCT). W związku z charakterystyczną budową trzykorzeniowych zębów przedtrzonowych przypominającą zwężonego zęba trzonowego opracowanie komory powinno umożliwić T-kształtny dostęp do ujść kanałowych (dwóch policzkowych i jednego podniebiennego). Trudnością nie bez znaczenia klinicznego w takim wypadku jest także wąska średnica kanałów, do których pierwszym narzędziem wprowadzonym na pełną długość roboczą może być pilnik C o rozmiarze 6 wg ISO. Tylko uważne postępowanie diagnostyczne i terapeutyczne pozwoli na prawidłowe opracowanie i wypełnienie systemu korzeniowego, zapewniając tym samym długoterminowe rokowanie bezobjawowego zachowania zęba w jamie ustnej po wykonaniu szczelnej odbudowy części koronowej.

\section{Oświadczenia}

Oświadczenie dotyczące konfliktu interesów

Autorzy deklarują brak konfliktu interesów

w autorstwie oraz publikacji pracy.

\section{Źródła finansowania}

Autorzy deklarują brak źródeł finansowania.

\section{Piśmiennictwo}

[1] Tronstad L. Drugi ząb przedtrzonowy szczęki. [w:] Endodoncja kliniczna. Wydawnictwo Lekarskie PZWL, Warszawa. 2004, s. 245.

[2] Barros DB, Guerreiro Tanomaru JM, Tanomaru-Filho M. Root canal treatment of three-rooted maxillary second premolars: report of four cases. Aust Endod J. 2009;35(2): 73-77.

[3] Velmurugan N, Parameswaran A, Kandaswamy D, Smitha A, Vijayalakshmi D, Sowmya N. Maxillary second premolar with three roots and three separate root canals-case reports. Aust Endod J. 2005;31(2): 73-75.
[4] Chauhan R, Singh S. Endodontic management of three-rooted maxillary second premolar in a patient with bilateral occurrence of three roots in maxillary second premolars. J Clin Exp Dent. 2012;4(5): e317320.

[5] Al-Khreisat AS, Khreisat IS, Khzouz WW. Three-rooted maxillary second premolar - a case report. Pak Oral Dent J. 2013;33(3): 547-549.

[6] Awooda EM, El Faki AK, Hassan NM, Sanhouri NM. Root Canal Treatment of Three - Rooted Maxillary Second Premolar Done by Undergraduate Dental Student - A Case Report. BJMMR 2015;8(6): 558563.

[7] Choudhary A, Rathore H, Sidhu S, Aggarwal VP, Malik S. Endodontic Management of Three Rooted Maxillary First and Second Premolars Two Case Reports. Int J Public Health Pap. 2017;2(1): 1-4.

[8] Gupta B, Gupta N, Thakur S, Gupta P, Jindal S. A rare clinical phenomenon of three rooted maxillary second premolar: A case report. Ann Dent Spec. 2017;5(3): 128-129.

[9] Yeh CS, Wong WB, Kan WYW, Tu MG. Root canal treatment of a three-rooted maxillary second premolar. J Dent Sci. 2017;12:95-97.

[10] Pecora JD, Sousa Neto MD, Saquy PC, Woelfel JB. In vitro study of root canal anatomy of maxillary second premolars. Braz Dent J 1992;3(2): 81-85.

[11] Abella F, Teixidó LM, Patel S, Sosa F, Duran-Sindreu F, Roig M. Cone-beam Computed Tomography Analysis of the Root Canal Morphology of Maxillary First and Second Premolars in a Spanish Population. J Endod. 2015;41(8): 1241-1247.

Zaakceptowano do edycji: 2018-10-16 Zaakceptowano do publikacji: 2018-12-05

Adres do korespondencji:

Kacper Nijakowski

Klinika Stomatologii Zachowawczej i Endodoncji

Uniwersytet Medyczny im. Karola Marcinkowskiego w Poznaniu

ul. Bukowska 70, 60-812 Poznań

e-mail: kacpernijakowski@interia.pl 